\title{
Constraints Regarding Skill Training of Rural Beneficiaries of Dhenkanal District of Odisha, India
}

\author{
Simantini Shasani* and Pranoy Ray \\ Department of Extension Education, College of Agriculture, OUAT, Bhubaneswar, India \\ *Corresponding author
}

\begin{tabular}{|c|}
\hline Keywords \\
\hline $\begin{array}{l}\text { Skill, Rural, } \\
\text { Beneficiaries, } \\
\text { Training, } \\
\text { Programme }\end{array}$ \\
\hline Article Info \\
\hline $\begin{array}{l}\text { Accepted: } \\
24 \text { August } 2018 \\
\text { Available Online: } \\
\text { 10 September } 2018\end{array}$ \\
\hline
\end{tabular}

\section{A B S T R A C T}

The present study entitled "Constraints regarding Skill Training of the rural beneficiaries of Dhenkanal district of Odisha" was undertaken with a view to study the different types of problem confronted by the rural beneficiaries with respect to the training provided. Analysis of the training was done in the context of topic selected, need assessment, development of training modules, use of training methods, conductance of training, feedback mechanism to find out the effectiveness of training as well as constraints perceived by the farmers related to training programmes. Around 120 beneficiaries were purposively selected for the study. The response was obtained from each individual respondent through pre-tested structured interview schedule for identifying the constraints. The findings of the study revealed that two training institute namely Krishi Vigyan Kendra(KVK) and Regional Institute of Training on Extension(RITE) which mainly deals with imparting training to the rural communities must address the recommendations like the content of training programme should be need based, more use of audio visual aids and regular transfer of technology for the beneficiaries, towards effective training programme of the training institutions for the upliftment of the rural community.

\section{Introduction}

India is predominantly agrarian society where farmers are enterprise owners in agriculture, and it is the responsibility of the agricultural extension system to transform the knowledge, skill and attitude of the farmers with the aim to enhance their productivity, production and profitability. An effective extension service makes for efficient farming. India is bestowed with large number of agricultural research institutions and various extension agencies spread across the country covering agriculture and allied sectors. The research system is supplemented with 690 Krishi Vigyan Kendras located in all the districts of the country for validating and acclimatising the technologies for local conditions. Krishi Vigyan Kendra (KVK) is innovative institution in India with a mandate of technology assessment, refinement and demonstration of technologies. KVKs undertake need based training of farmers, farm women and rural youths; conducts on farm trials for technology refinement and frontline demonstrations to demonstrate the latest agricultural technologies to the farmers as well as the extension workers, work as resource 
and knowledge center. "Seeing is believing" and "Learning by doing" are main methods of imparting skill training.Regional Institute of Training and Extension (RITE) are the state level training institutes for skill development in agricultural sector among the various extension agencies working for agricultural development. Empowerment of the small and marginal farmers through education, reforms and development will ensure better, efficient and strengthening of Indian agriculture. Motivating and imparting education to small farmers will help in development of the sector more importantly improving the economic status of the poor farmers. Ponnusamy (2002) observed that training of shrimp farmers based on their need assessment would not only help in honoring their skills but also updating them. Thus training in general and skill training in particular became the buzzwords in the context of plans and programmes decided for the development and welfare of the society at large. In this context and background of various training institutions which are engaged in imparting training to farmers have been identified and an attempt therefore made to assess the constraints of the training programmes.

\section{Materials and Methods}

The study was conducted in Dhenkanal district of Odisha. A sample of 120 beneficiaries of training programmes was taken from three villages each from three blocks of Dhenkanal district. Both purposive and random sampling procedure was followed for selection of district, blocks, panchayats, villages and respondents. The beneficiaries were selected randomly from the registered trainees of the KVK training programmes, who attended during last three years. The study was conducted after the completion of trainings, so it was "Ex-post facto" in nature. The response was obtained from each individual respondent through pre-tested structured interview schedule prepared for the collection of data. The variables under the constraints were included in broad divisions like planning, social, technological, economic, and institutional. The scale points like fully agree, partially agree and disagree were used in the study. The collected data was tabulated and analyzed with the use of suitable statistical tools and techniques.

\section{Results and Discussion}

It is important to understand the constraints faced by the farmers in order to increase their effectiveness and it also helps to give suggestions to the policy makers. By knowing the constraints new policy can be generated for betterment of the rural people. So the constraints faced by the beneficiaries were categorized under following components.

\section{Constraints in planning training programme}

This planning is an essential part of the training programmes. Effective planning provides cooperation and coordinated efforts as well as facilitates sequential exclusion of task by reducing uncertainties. Data collected from the respondents have been analysed and presented below.

From the table 1 it was observed that respondents felt most the constraints of planning not done from user perspective (rank-I).

According to most of them audio visuals were not arranged properly (rank-II). Problems like skill prioritisation (III), improper problem diagnosis (IV), basic need not properly accessed (V), participatory approach not followed (VI), lesson plan not properly developed (VII), teaching aids not designed properly (VIII) were also arouse during training. 


\section{Social constraints}

It is one of the important attributes because it reflects the attitude or personal opinion of the respondents towards the training programme. As per the table 2 it was observed that low risk bearing ability of farmers was the most important social constraint with mean score of 2.47. It might be due to their small and marginal land holding, they were unable to bear risks as agriculture is their primary source of income.

After that lack of awareness about new technology, Non co-operation and coordination among farmers, Lack of family support for adoption of new technology, Lack of initiative or poor leadership, Lack of confidence among farmers ranked as 2nd, 3rd, 4th, 5th and 6th respectively.

\section{Technological constraints}

The farmers usually not acquainted with new technologies generated and prefer traditional farming. Besides they do not have good knowledge about easy availability of quality inputs recommended in training programmes. Attempts were therefore made in the study to identify the technological constraints faced by the farmers. The data obtained from the analysis is presented below.

The table 3 intimated that the most important constraint was non availability of quality inputs locally with a highest mean score of 2.35. It is followed by non- availability of production inputs (rank II). Rest two constraints were complex technology not easily understood (rank III) and less number of on-campus training (rank III).

Table.1 Constraints in planning training programme

\begin{tabular}{|c|l|c|c|}
\hline S. no. & \multicolumn{1}{|c|}{ Constraints } & Mean score & Rank \\
\hline $\mathbf{1}$ & Participatory approach not followed & 1.68 & VI \\
\hline 2 & Basic need not properly accessed & 1.78 & V \\
\hline 3 & Improper problem diagnosis & 1.81 & IV \\
\hline 4 & Planning not done from user perspective & 2.06 & I \\
\hline 5 & Skill prioritisation not done & 2.01 & III \\
\hline 6 & Lesson plan not properly developed & 1.66 & VII \\
\hline 7 & Teaching aids not designed properly & 1.61 & VIII \\
\hline 8 & Audio visuals not arranged properly & 2.2 & II \\
\hline
\end{tabular}

Table.2 Social constraints

\begin{tabular}{|c|l|c|c|}
\hline SI. No & \multicolumn{1}{|c|}{ Constraints } & Mean score & Rank \\
\hline $\mathbf{1}$ & Lack of family support for adoption of new technology & 2.10 & IV \\
\hline $\mathbf{2}$ & Lack of awareness about new technologies & 2.26 & II \\
\hline $\mathbf{3}$ & Non co-operation \& coordination among farmers & 2.16 & III \\
\hline $\mathbf{4}$ & Lack of confidence among farmers & 2.07 & VI \\
\hline $\mathbf{5}$ & Lack of initiative or poor leadership & 2.08 & V \\
\hline & Low risk bearing ability of farmers & 2.47 & I \\
\hline
\end{tabular}


Table.3 Technological constraints

\begin{tabular}{|c|l|c|c|}
\hline Sl.no. & \multicolumn{1}{|c|}{ Constraints } & Mean score & Rank \\
\hline $\mathbf{1}$ & Non availability of production inputs & 2.25 & II \\
\hline 2 & Difficult to understand Complex technology & 2.18 & III \\
\hline 3 & Non availability of quality inputs locally & 2.35 & I \\
\hline 4 & Less number of on-campus training & 1.94 & IV \\
\hline & Average & 2.18 & \\
\hline
\end{tabular}

Table.4 Economic constraints

\begin{tabular}{|c|l|c|c|}
\hline SI. No & \multicolumn{1}{|c|}{ Constraints } & Mean score & Rank \\
\hline $\mathbf{1}$ & High cost of technology & 2.09 & IV \\
\hline $\mathbf{2}$ & Labour intensive technology & 1.98 & V \\
\hline $\mathbf{3}$ & Lack of credit facility & 2.53 & I \\
\hline $\mathbf{4}$ & Poor economic condition & 2.45 & II \\
\hline 5 & Lack of knowledge about crop loan and insurance & 2.28 & III \\
\hline
\end{tabular}

Table.5 Institutional constraints

\begin{tabular}{|c|l|c|c|}
\hline SI. No & \multicolumn{1}{|c|}{ Constraints } & Mean score & Rank \\
\hline 1 & Week extension system at village level & 2.23 & I \\
\hline 2 & No timely supply and services by KVK & 2.20 & II \\
\hline 3 & No accommodation facility for on-campus training & 1.63 & IV \\
\hline 4 & Insufficient demonstration & 2.16 & III \\
\hline & Average & 2.05 & \\
\hline
\end{tabular}

Table.6 Comparative analysis of the constraints

\begin{tabular}{|l|l|c|c|}
\hline Sl. no & Constraints & A verage mean score & Rank \\
\hline $\mathbf{1}$ & Planning training programme & 1.85 & V \\
\hline $\mathbf{2}$ & Social & 2.19 & II \\
\hline $\mathbf{3}$ & Technological & 2.18 & III \\
\hline $\mathbf{5}$ & Economic & 2.26 & I \\
\hline
\end{tabular}

\section{Economic constraints}

Farmers need adequate financial support in adoption of technologies over knowledge gained through training programs. The economic constraints of the respondents were collected, analysed and presented below.

Regarding ranking of the economic constraints the data in the table 4 revealed that 
the respondents had expressed the important constraints lack of credit facilities (rank-I) with mean score 2.53 followed by poor economic condition (rank-II), lack of knowledge about crop loan and insurance, high cost of technology (rank-III).

\section{Institutional constraints}

The good learning environment attracts effective learning. So proper institutional arrangement is required with well- furnished training hall and teaching aids.

The table 5 intimated that most important constraint was week extension system at village level according to the respondents. Other constraints were no timely supply and services by KVK (rank-II), insufficient demonstration (rank-III) with mean score 2.16 and no accommodation facility for on-campus training (rank-IV).

The respondents of the study area had stated more economic constraints i.e. having highest mean score 2.26 (rank-I). It was followed by social constraints (rank-II), technological constraints (rank-III), institutional constraints (rank-IV) and constraints of planning training programme (rank-V) (Table 6).

In conclusion, Findings of the study intimated that the beneficiaries had very pertinent constraints in attending KVK training programmes. According to them the major constraint was economic constraint. They are facing the problems like lack of credit facilities and labour intensive technology and their poor economic status. In many cases social constraints act as barrier for further development. They are afraid of taking risk sometimes because of unpredictable consequence. They are lacking awareness about the new technology to be used. Other social constraints stated by them were lack of leadership, lack of family support in adoption of new technology etc. in the matter of technological constraints they were worried about non availability of quality inputs locally and the technologies used are complex for some people. There were also some constraints regarding planning of the training programmes and institutional constraints. Hence to increase the effectiveness of training some suggestions may be taken care of. Regular transfer of technology from training institutions to the farmers may be done. Proper arrangement of audio visual aids, strengthening farmers' extension system and regular follow up action with proper guidance may be recommended. These will definitely create good impact towards upliftment of rural beneficiaries.

\section{References}

Ahmad Nafees, Singh SP, Parihar P, 2012, Farmer's assessment of KVK training programme, Economic Affairs. 57(2); $165-168$

Gaikwad A.B and Suryawanshi D.B, 2012, Constraints faced by extension personnel in transfer of technology, Bioinfolet, 9(4); 728-729

Hiremath S.M \&Nagaraju M.V, 2009, Evaluation of front line demonstration trials on onion in Haveri district of Karnataka, Karnataka Journal of Agricultural Sciences, 22(5); 1092-1093

Mishra D.K, Tailor R.S, 2009, Impact of frontline demonstration on yield enhancement of potato, Indian Research Journal Extension Education, 9(3)

Nagaraj K.H, Mazarasyed, 2016, Impact of integrated farming system in Ramnagar district, International Journal of Agricultural Environment \& Biotechnology, 9(3); 429-434

Patel R.N, Prajapati M.R and Patel V.T, 2015, Training need assessment of castors growers, Gujarat Journal of Extension Education, 26(1); 106-107 
Ponnusamy, K., K. Gopinathan, M. Kumaran and M. Krishnan 2001 Constraints analysis in adoption of shrimp farming in Tamil Nadu. Journal of Applied Fisheries and Aquaculture. 1(1): 103105.

Rathore J.S, 2005, Impact of KVK Pali (Rajsthan) on behavioural change of farmers, thesis unpublished, submitted to Department of Extension Education, Institute of Agricultural Sciences, BHU, Varanasi.
Sharma Manoj, Singh Gurdep, 2014, Impact Evaluation of training programme on Dairy farming in Punjab State, Indian Research Journal of Extension Education.14(1).

Singh Mukesh, Tambe S.B, 2014, Impact of training on Agricultural Technology knowledge (Adoption) of farmers. Bharatiya Krishi Anusandhan Patrika, 29 (2) Singh N.P, 1982, Training needs of farmers, Indian Journal of Extension Education, 18(1-2); 66-72.

\section{How to cite this article:}

Simantini Shasani and Pranoy Ray. 2018. Constraints Regarding Skill Training of Rural Beneficiaries of Dhenkanal District of Odisha, India. Int.J.Curr.Microbiol.App.Sci. 7(09): 3282-3287. doi: https://doi.org/10.20546/ijcmas.2018.709.407 